\title{
Intergenerational Educational Transmission within Families: \\ An Analysis and Microsimulation Projection for Austria
}

\section{Martin Spielauer}

\begin{abstract}
In this contribution we study intergenerational educational transmission within families in Austria. The paper is divided into an analytical part and a synthesis of the resulting behavioural models to a comprehensive computer microsimulation model that is used to project the future educational composition of the population. The models are based on retrospective event history data collected in the special programme of the 1996 micro-census, which was also used to generate the starting population for projections. The analysis of school choices reveals a very strong influence of parental educational attainment leading to strong intergenerational transmission mechanisms within families, i. e., considerable intergenerational persistence of educational careers within families. In contrast to the continuing educational expansion at the population level, very stable behavioural relationships can be found on the micro level when accounting for parental educational attainment. Our projections reveal that the educational expansion that we experienced in the last decades will continue at a very moderate speed in the next decades until an equilibrium is reached. In the equilibrium, half of the population will obtain a Matura diploma of which $30 \%$ will also graduate from university.
\end{abstract}

\section{Introduction}

To which extent does the educational background of parents influence the school careers of their offspring? How large are urban-rural differentials regarding school choices? Does gender still matter? In order to provide some quantitative answers to these questions, the first part of this study will focus on graduation rates in the Austrian school system. The most important dynamic we observe on the macro level is an overall educational expansion: with every birth cohort an increasing number of people reach higher levels of education. Does this expansion result from an overall increase of higher education graduation rates in all socio-demographic groups or is it rather the result of changes in the educational composition of the parents' generation?

While we observed considerable changes on the micro level in (diminishing) gender and rural-urban differentials as well as an increase of higher education transition 
rates especially in the lower socio-economic strata until the 1970s, transition rates by gender, municipality type and parents' education have been staying almost unchanged since the past two decades. What does this mean for the future? Assuming unchanged behavioural relations on the micro level, when will the population reach a stable equilibrium in its educational composition? What will the resulting educational composition of the population look like?

In order to answer these questions, we need to consider additional processes that influence the future educational composition of the Austrian population: partnership formation and fertility. We will apply current patterns of couple formation by educational attainment and use computer micro-simulation in order to check for future consistency, i. e., if people find partners corresponding to today's educational and age patterns in the future as well.

The second related behaviour that affects the future educational composition of the population are fertility differentials between educational groups. In the past, we observed very typical demographic patterns that lead from very high fertility differentials between educational groups at the beginning of the last century to the emergence of the two-child norm and corresponding small fertility differentials, with fertility rates around replacement level in all groups. This process reversed in the second half of the past century (at generally lower fertility levels but with increasing fertility differentials).

In the second part of the paper, we will move from the analysis to the synthesis by putting the pieces together into a comprehensive microsimulation model. We finally apply the microsimulation model to project the educational composition of the population into the future. As all parameters are assumed to be time-invariant, the educational composition converges towards a stable equilibrium. In order to determine the effect of fertility differentials on this equilibrium, we will create a second scenario of uniform fertility behaviours and use the resulting equilibriums for comparative analysis.

Both the starting population and the behavioural modules are based on the Austrian micro-census of June 1996. It contains retrospective event history data regarding educational and fertility biographies. For the computational implementation of the model we use the FAMSIM+ computational platform developed by the author (Spielauer, 2002; Spielauer 2003).

\section{School choices in Austria: school system and individual transition data}

For the purpose of this study, a simplified model representation of the Austrian school system is used. The model distinguishes nine school types ranging from primary school to university. We do not distinguish between different school types within this broad typology. For example, all apprenticeships are seen as one school type without accounting for the wide range of different training programmes. In an 
international comparison, the Austrian school system is characterised by a high importance placed on the dual system of apprenticeships and the high weight on vocational education in general. A very early first school choice is made at the age of 10 years and a relatively small percentage of people hold academic titles ( $8 \%$ of the total population; $12 \%$ of the young of university leaving age). Another important characteristic in the context of our study, especially regarding the timing of birth, is the long study duration of university students (an average of 7.5 years for an M.A. programme) and the high dropout rates in Austrian universities (around 50\%). With $6.3 \%$ of GDP spent on education, Austria has one of the highest educational expenditures. The effectiveness of these investments is subject to continuing national debate. For a detailed discussion of the Austrian school system, see Schmid (2003), bmbwk (2004), Bacher (2003) and Spielauer et al. (2004).

\section{Figure 1}

School types and transitions in the model representation of the Austrian school system

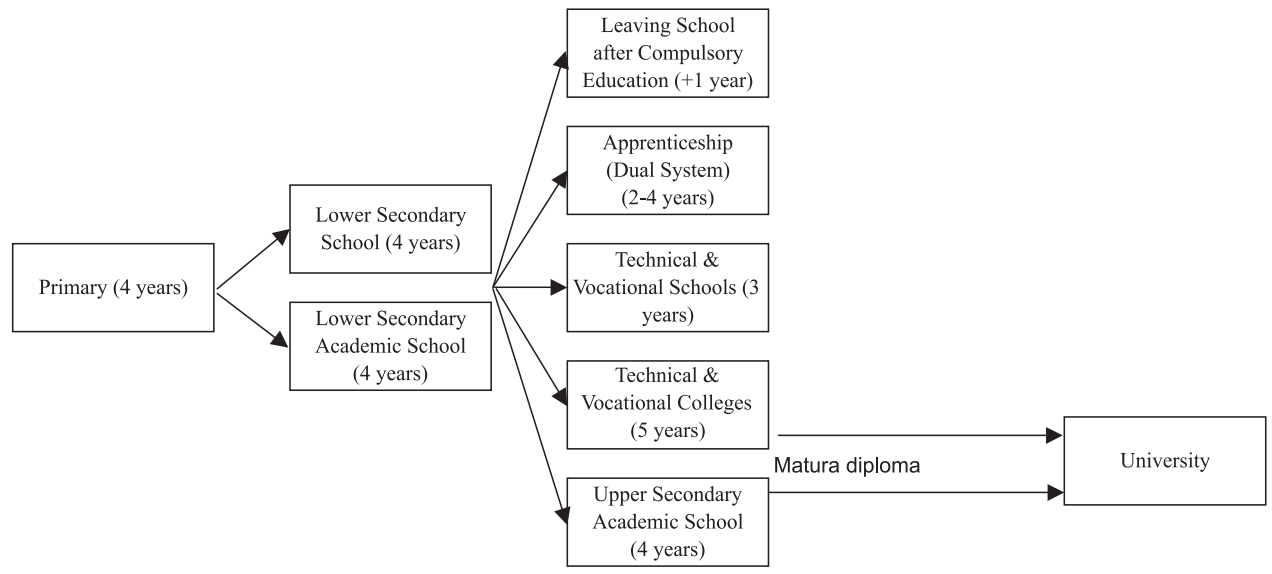

Regarding the modelling of school transitions, we have chosen an outcome-oriented approach. School careers which include incomplete school spells followed by completed ones are treated and coded as if the student had stayed in the second school for the entire duration. As with the transition probabilities, the education duration within the different school types is modelled by taking into account various individual characteristics. As these durations also include preceding unfinished school spells, there is no one-to-one correspondence to the "true" duration distribution within schools. For this reason, simulated numbers will differ from the period enrolment rates observed in different school forms, as enrolment rates include school dropouts (and exclude students who will eventually switch from one school type to another after dropping out), whereas graduation numbers and ages should correspond to "true" numbers. To avoid distortions in the school leaving age due to possible uncompleted school spells at the end of the educational career, e. g., university dropouts who might have been enrolled at university for several years, two additional 
school types are modelled. First, university dropouts are treated as if they attended another school type with duration times different to those of university graduates. Second, an additional school type "Short Colleges" is introduced, which sums up all kinds of additionally existing programmes as well as started but not finished school spells in all secondary schools considered. In contrast to all other schools under study, "Short Colleges" do not lead to a different educational status or category and will not be discussed in detail below.

Individual school careers are modelled as a series of three school choices at the three main transition points: after primary school, lower secondary school and upper secondary school. All schools are assumed to start in September and finish in August, with duration times in full years.

The data source for this study is the special programme of the Austrian micro-census from June 1996, which contained a questionnaire on educational history, marriage, and biography of births. The main variables for our study concern the educational history. While the micro-census contains all school spells, i. e., also those that did not lead to graduation of the respective school, this information was recoded to graduation histories together with school durations, measured as the time from graduation from the previous school to graduation from the current school.

We identified and use the educational attainment of parents, the rural/urban setting and gender as main covariates of individual school careers:

Parents' education: We use the five categories (1) compulsory, (2) apprenticeship, (3) vocational and technical school, (4) Matura diploma and (5) university for the parents' education. If both parents do not have the same educational level, the highest education of either is employed. These educational categories were also used in our analysis of partnerships by education.

Municipality: the municipality type indicates whether a person lived in a rural or urban area at the age of fifteen. The information is obtained by self-evaluation of the respondent and - in the aggregate-roughly corresponds to the municipality types below and over 20.000 inhabitants.

Together with the sex of the respondent, we obtain 20 groups of students for which educational choices were analysed over time, i. e., by birth cohort. Regarding individual school careers, we distinguish seven types of the highest educational attainment reached: (1) compulsory, (2) apprenticeship, (3) vocational or technical schools, (4) vocational or technical college with Matura, (5) secondary academic school with Matura, (6) university and (7) university dropouts. This typology was also used in the investigation of fertility differentials by education.

In contrast to the basic programme of the micro-census, the special programme is a voluntary one. In our sample, 26639 out of 33811 individuals answered the questions on education. In order to avoid a possible systematic error in the data, the smaller sample of the special program of the micro-census was re-weighed by the variables highest education, gender, provincmee and age in order to meet the educational distribution as observed in the full survey. (For a documentation, see Schwarz and Spielauer 2003). 
Existing studies on social selection in the Austrian education system mainly concentrate on university education, e. g., Landler (1997); examples for the few studies that were conducted on social selection in secondary schools are Bacher (2003) and Bauer (1996). For Germany, Blossfeld (1998) has carried out extensive research on intergenerational education transmission, educational participation and educational processes. In their comparative study of change in educational stratification in 13 industrialised countries, Shavit and Blossfeld (1993) show that inequalities in educational opportunities have been remarkably stable since the early twentieth century. Henz (1997) finds that in particular transition rates after elementary school are highly selective. Klemm (2000) likewise emphasises that, despite educational expansion in Germany, considerable differences in educational chances by regional and social background still continue to exist. While our findings for Austria arrive at similar conclusions, the grade of selectivity and intergenerational persistence might still come as a surprise.

\section{The first educational choice}

The first educational choice is made after primary school, usually at the age of ten. It is a choice between two school types: the lower secondary school (Hauptschule) and the lower academic secondary school (AHS) ${ }^{1}$

1 Limiting the choice to the two school types considered is a simplification, as it ignores special schools for handicapped or maladjusted children (Sonderschule). This school type is treated as "lower secondary school" (Hauptschule) here. The education system has slightly changed over the years; for instance, no prevocational school (Polytechnische Schule) existed in the early days but pupils had the possibility of attending primary school (Volksschule) up to the $8^{\text {th }}$ grade. In this case, the second four years were treated as lower secondary school. Over the past decades, a steady increase of the rate of children graduating from the lower secondary academic school has been observed. From the 1935-39 to the 1975-79 birth cohort, the proportion of graduating children increased from around $12 \%$ to $27 \%$. As seen in the figure below, an increase can be observed for both sexes, with girls starting at a much lower level, especially in cities but then catching up with the birth cohort 1965 and even overtaking male rates in rural areas. Rural-urban differences are considerable, with rates being twice as high in cities ( 40\%) than in rural areas for the most recent birth cohort. A gap of 20 percent points has been staying almost constant since the last decades. 
Figure 2:

Lower secondary academic school graduates by gender and municipality type over five-year-birth cohorts from 1935 to 1979. Source: Micro-Census June 1996

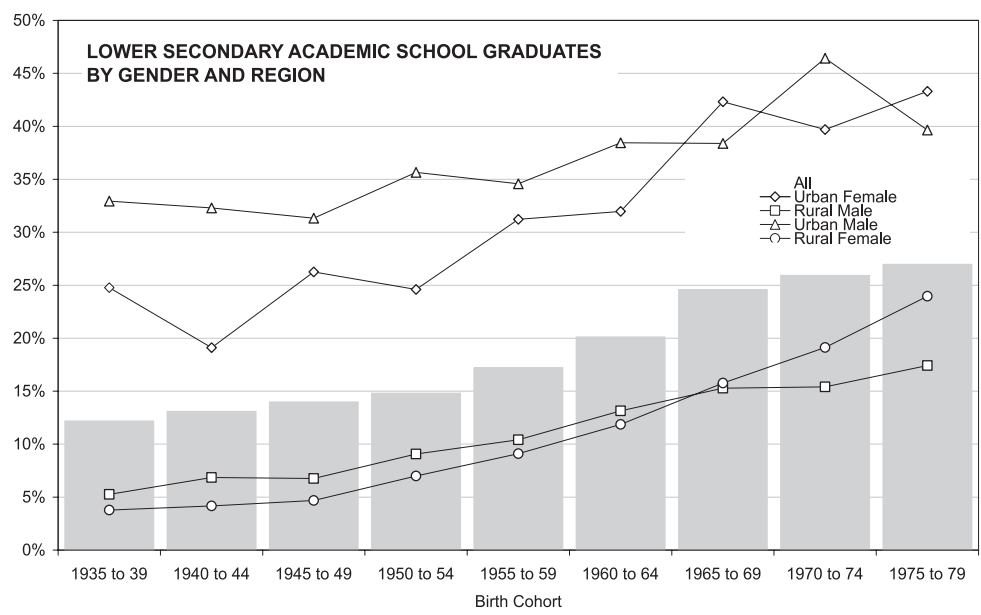

Besides rural-urban differences, it is the parents' educational attainment, defined as the highest educational attainment of both parents, that shows the greatest influence on school choice. While only $10 \%$ of the children of parents with compulsory education graduate from lower secondary academic schools, this rate reaches almost $80 \%$ for the offspring of university graduates.

Figure 3:

First school choice by parents' educational attainment for the 1965-79 birth cohort. Source: Micro-Census June 1996

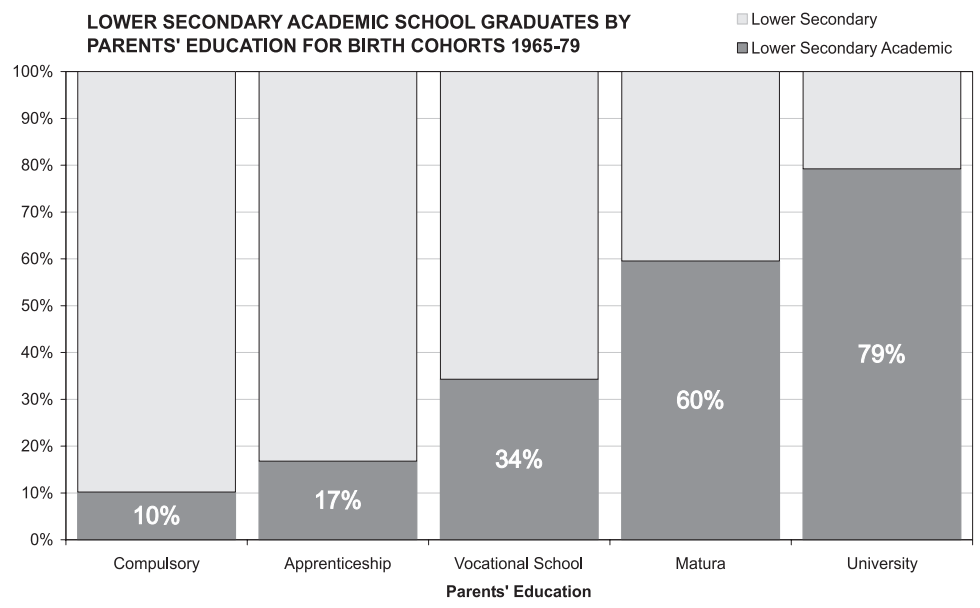

By further disaggregation of the rates by sex and municipality type, the rates are closely ranked by parents' education, municipality type and sex, with the highest rate 
( $86 \%$ for urban daughters of university graduates) being more than 12 times higher than the lowest rate ( $7 \%$ for rural sons of parents with compulsory education).

Figure 4:

First school choice by parents' educational attainment, gender and municipality type for the birth cohort 1965-79. Source: Micro-Census June 1996

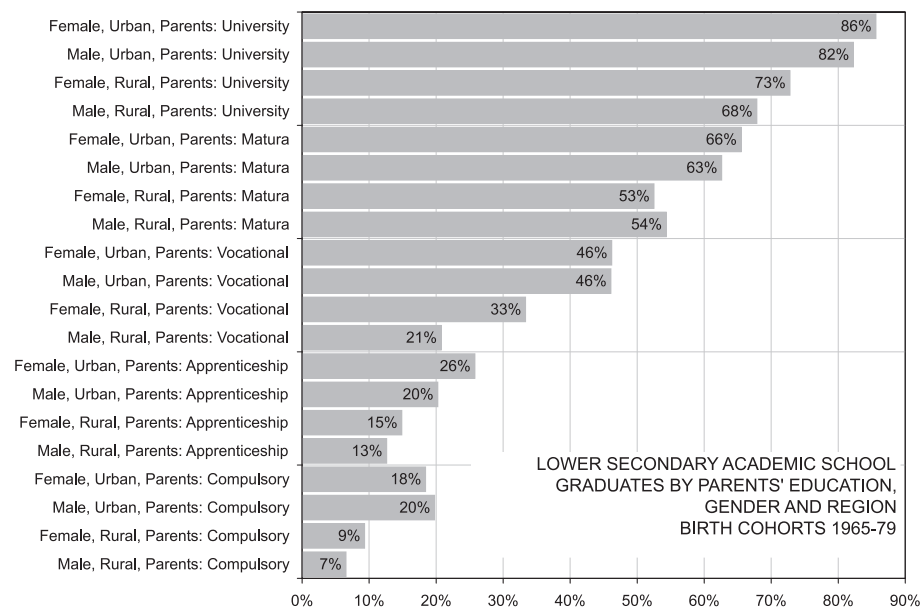

For the educational backgrounds of parents, decisions about schooling have followed very stable patterns over time, with no significant changes in the percentage of children graduating from lower secondary academic school from the 1960s onwards. For the last two decades, percentages have stayed at around 10\%-17\%-34\%-60\%$80 \%$, depending on the parents' education.

Figure 5:

Lower secondary academic school graduates by parents' education over five-year-cohorts from 1935 to 1979. Source: Micro-Census June 1996

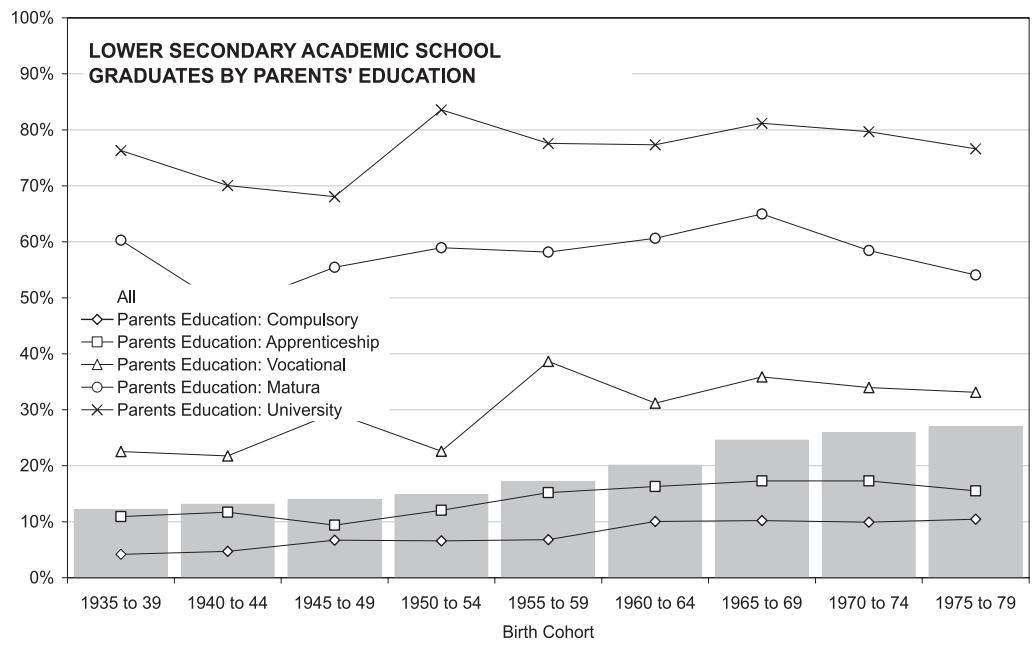


Further disaggregation by gender and municipality type shows that changes over time to a large extent can be attributed to the catch-up effect of female students, especially in rural areas. In contrast, rates for urban males have remained almost unchanged for the last 50 years. The individual contribution of the variables gender, municipality and parents' education can be best explored by regression analysis. For this purpose, a logistic regression was estimated separately for all five-year birth cohorts.

Table 1:

Logistic regression coefficients, standard error and odds ratios for graduating from lower secondary academic school for five-year birth cohorts from 1935 to 1979

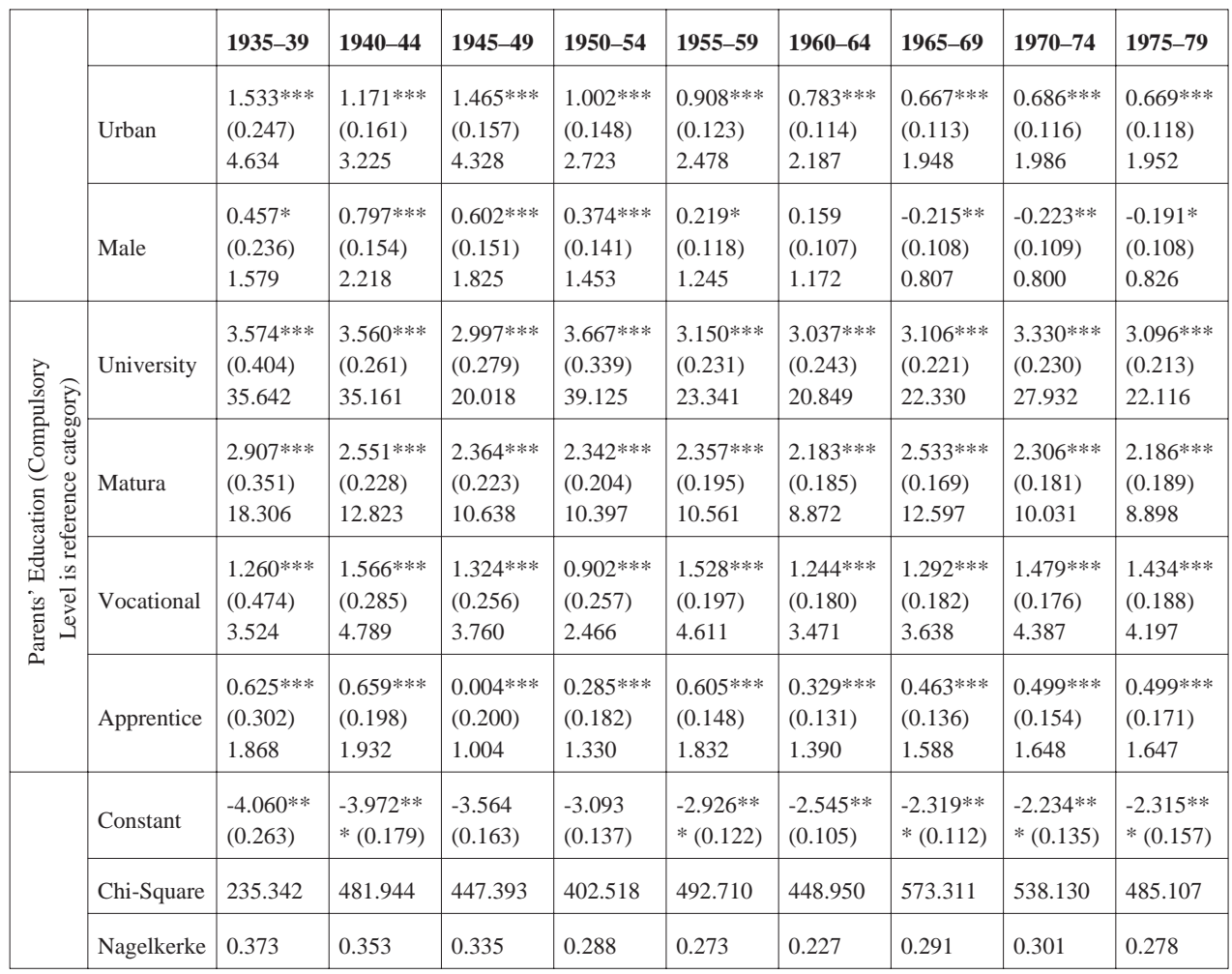

Models estimated from the June 1996 Micro-Census data; significance levels are indicated by *** over $99 \%$, ** over $95 \%$ and $*$ over $90 \%$

The regression coefficients of the logistic regression listed in the table explain the influence of several factors on compulsory education for each cohort separately. Most of the regression coefficients are highly significant (over 99\%), except gender (male) in the turning years of the birth cohorts 1955-64, when female students catch up and overtake male students. As depicted in the following figure, the regression coefficients regarding the influence of parents' education (and therefore the odds ratios) stayed relatively stable for the second half of the century, whereas the "advan- 
tage" of being male regarding the probability of graduating from lower secondary academic school disappeared and turned negative over time. In addition, the "advantage" of living in urban municipalities diminished over time. The increase of the constant term indicates a general rise of probabilities for all groups (cohort effect) which, as with the influence of gender and municipality type, levelled off for the three most recent cohorts.

\section{Figure 6:}

Regression coefficients of the logistic regression model estimated separately for all five-year birth cohorts from 1935 to 1979

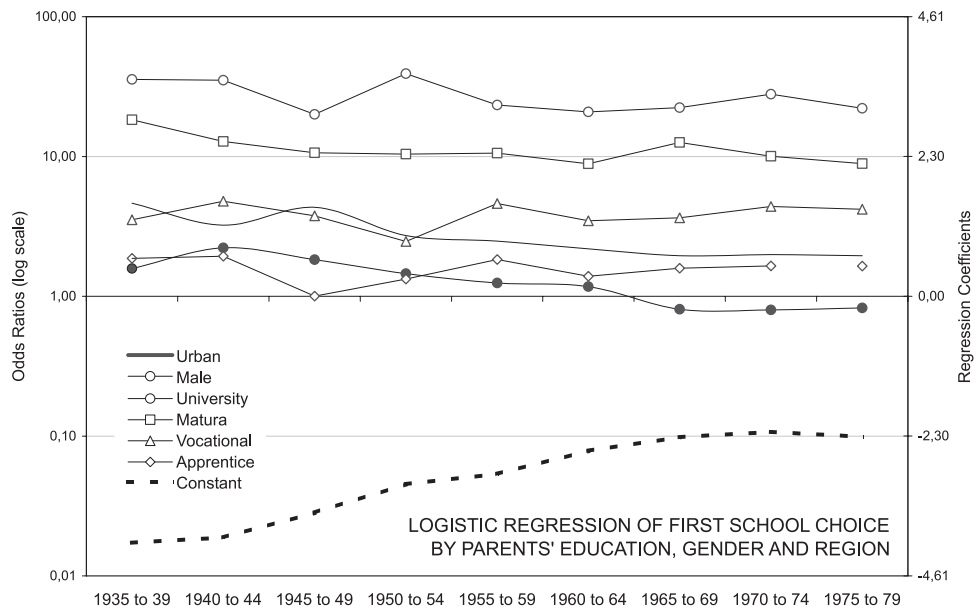

While aggregated school transition rates calculations from the micro-census sample are largely consistent with transition rates calculated from schools statistics, e. g., by Biffl (2002) and Landler (1997), the latter do not allow for detailed studies on the influence of the social background except for university students. Census data to some extent do contain comparable information. Bauer (1996) asserts in her evaluation of census data that the educational career of children is crucially influenced by the employment position of the head of the family. In her comparison of census data from 1981 and 1991 she found the difference of the status composition of parents in different school types to be persistently high.

\section{The second educational choice}

The second educational choice is usually made at the age of 14, at the transition point from lower to upper secondary education. While the first choice basically is a choice between two types of schools, namely the lower secondary school and the lower secondary academic school, educational career paths meet again at this point in order to branch to a wide set of school types and apprenticeships. The upper secondary level offers several possibilities for further education: The (1) apprenticeship, 
taking three to four years, combines specific job-related training according to the chosen occupation in firms and vocational schooling. Other possibilities are (2) secondary vocational and technical schools, which generally last three years and lead to a certificate. Students attending (3) secondary vocational and technical colleges finish with a final exam after five years of successful schooling, the Matura, a diploma which is essential for entering university and other post-secondary colleges or academies. Secondary vocational colleges are primarily commercial academies, while secondary technical colleges allow specialisation in certain technical industries. A further alternative is (4) the upper secondary academic school, which provides its attendants mainly with general knowledge. It takes four years and successful graduation also requires passing the Matura. The fifth (5) possible choice we consider in our model consists in leaving school after finishing compulsory schooling. This can be done by attending any school for another year in order to fulfil the nine years of compulsory school.

The second educational choice is of tremendous importance since it largely determines final educational attainment and access to higher education.

Using parents' education, rural/urban setting, gender and the previous school choice as grouping variables, students at this decision point can be assigned to 40 possible groups. For the purpose of this paper, we want to highlight two main descriptive results: the importance of the first school choice on the second regarding the probability to obtain a Matura diploma and the educational attainment at the secondary level by parents' educational attainment. A full study of individual transition rates and their dynamics over time can be found in Spielauer et al. (2004). The following figure displays both the high pre-selection of chances to obtain a Matura diploma by the previous school attainment and the continuing influence of parents' educational attainment. 
Figure 7:

Probability to obtain a Matura diploma by previous school attainment and parents' education for the birth cohorts 1965-79. Source: Micro-Census June 1996

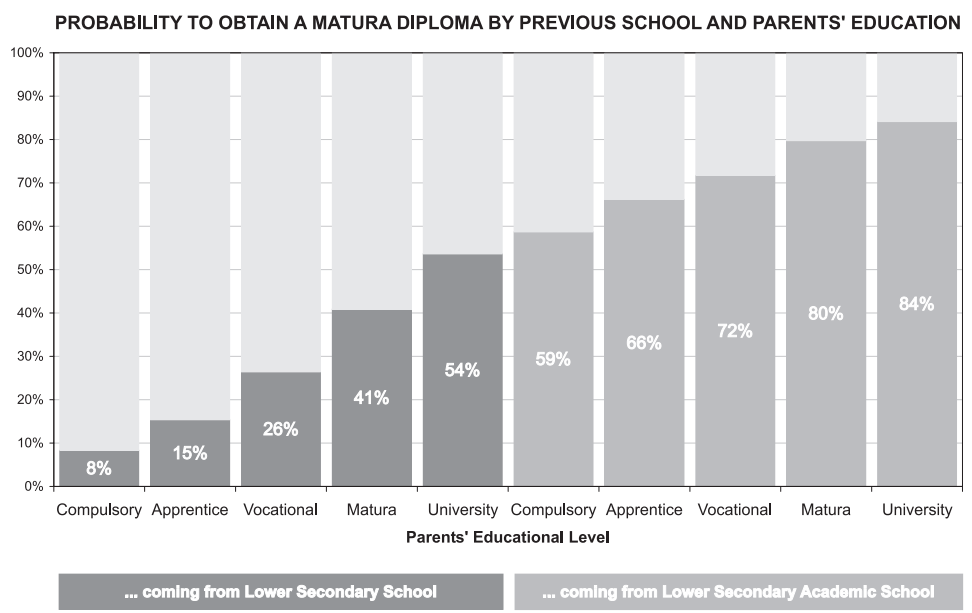

The following figure shows the secondary school attainment, distinguishing between the five modelled school types by parents' education.

Figure 8:

Upper secondary school attainment by parents' educational attainment, birth cohort 1965-79.

Source: Micro-Census June 1996

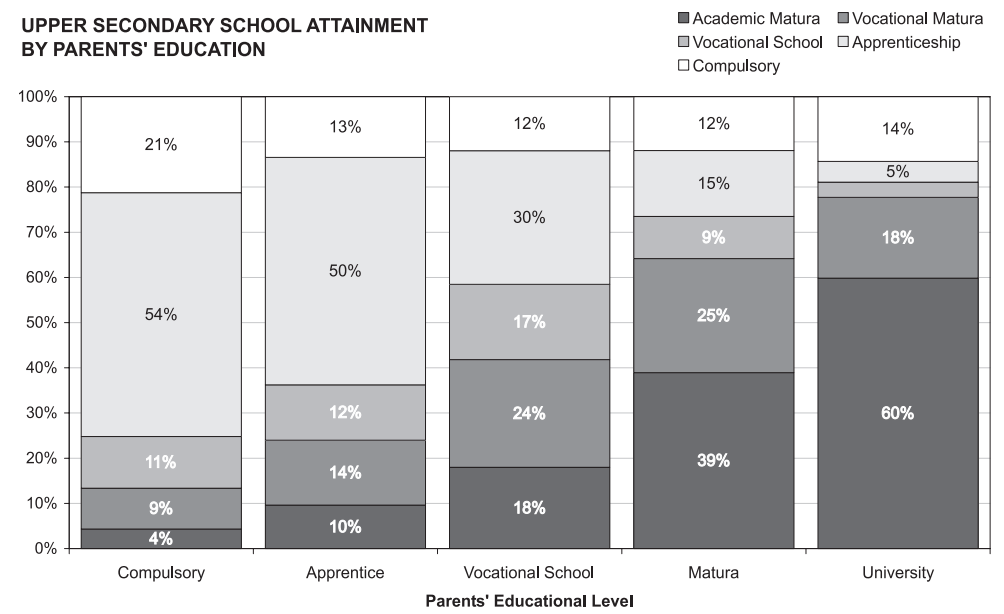

The graduation probabilities calculated from micro-census data vary considerably from period transition rates at the age of 14 . Due to high dropout rates period transition rates are a rather problematic indicator of the expected final educational attainment. e. g., many students who do not intend to continue their education often use the first year of upper secondary schools and colleges as substitute for the regular $9^{\text {th }}$ grade of compulsory education, namely the prevocational school. As we consider 
these individuals as school leavers after compulsory education, our results show lower numbers in upper secondary school attendance compared to period measures on school enrolment. Biffl (2002) calculates the transition rates from compulsory education to the subsequent education level. A rough comparison of our findings with the results of Biffl is provided in the following table. While the rates cannot be compared directly due to different definitions and observation periods (we compare graduation rates of the birth cohorts 1965-79 with period school transition rates of the school year 1988/89), some interesting observations and interpretations can be derived.

Table 2: Transition and graduation rates after lower secondary school (in \%)

\begin{tabular}{|l|l|c|c|}
\hline \multirow{4}{*}{$\begin{array}{l}\text { After Lower } \\
\text { Secondary } \\
\text { School }\end{array}$} & Leaving School after Compulsory Education & $\begin{array}{c}\text { Transition Rates } \\
\text { School Year 1988/89 }\end{array}$ & $\begin{array}{c}\text { Graduation Rates } \\
\text { Birth Cohort 1965-79 }\end{array}$ \\
\cline { 2 - 4 } & Apprenticeship & $22 \%$ & $15 \%$ \\
\cline { 2 - 4 } & Vocational or Technical School & $49 \%$ & $54 \%$ \\
\cline { 2 - 4 } & Vocational or Technical College & $20 \%$ & $14 \%$ \\
\cline { 2 - 4 } & Upper Secondary Academic School & $8 \%$ & $13 \%$ \\
\hline \multirow{4}{*}{$\begin{array}{l}\text { After Lower } \\
\text { Secondary } \\
\text { Academic } \\
\text { School }\end{array}$} & Leaving School after Compulsory Education & $1 \%$ & $4 \%$ \\
\cline { 2 - 4 } & ApprenticeshipC5,0,0,0,0,0 & $10 \%$ & $12 \%$ \\
\cline { 2 - 4 } & Vocational or Technical School & $10 \%$ & $9 \%$ \\
\cline { 2 - 4 } & Vocational or Technical College & $39 \%$ & $24 \%$ \\
\cline { 2 - 4 } & Upper Secondary Academic School & $39 \%$ & $51 \%$ \\
\hline
\end{tabular}

Source: Biffl (2002), micro-census 1996, author's own calculations

The most dominant educational track for those who attended a lower secondary school is an apprenticeship. In contrast to the fulltime school system, the supply of apprenticeships is market driven and may involve waiting periods, which students spend either outside the school system (accounted for "no further education" in Biffl's calculation) or in fulltime schools, most typically of the vocational and technical type. This fact may explain the differences between transition and graduation rates of the first three educational tracks. We also find a considerable difference regarding students obtaining a Matura. This indicates that many students who initially enrolled in other schools or temporarily left the school system finally attend schools leading to a Matura.

For students who attended a lower secondary academic school, apprenticeships are of minor importance and a comparison of data indicates that almost half of the students starting an apprenticeship training do not complete it or also obtain a higher secondary degree. The differences of rates regarding vocational and technical col- 
leges can be explained by the very high dropout rates. A comparison of rates indicates that most dropouts obtain an academic Matura instead, while a considerable proportion also increases the group of "no further education".

Landler (1997) examined attendance of the two school types leading to a Matura diploma, namely secondary academic school and secondary vocational college. He observed a steady shift from the former towards vocational and technical colleges over the last decades. In the school year 1994, around 55\% of all males and 50\% of all females who obtained a Matura diploma attended vocational or technical colleges. Our data show similar results: for the 1990-94 graduation cohort, $49 \%$ of all males and $47 \%$ of all females who obtained a Matura diploma attended vocational or technical colleges. Our study reveals that not only the probability to obtain a Matura diploma is highly influenced by the parents' education, but also the type of Matura: the higher the parents' educational level, the higher the share of the academic Matura (3:1 in the highest vs. 1:2 in the lowest group; see fig. 8).

\section{University education}

The third educational transition regards the decision of students having passed the Matura diploma to continue education by enrolling at-and graduating from-university. Due to high dropout rates in Austria, ranging at around $50 \%{ }^{2}$ and the high variance in study duration that is often considerably higher than the regular time foreseen by the curricula, the following analysis also includes education duration. In contrast to the previous school careers, dropout rates and study durations have to be explicitly taken into account, also due to their high dependence on socio-demographic factors like gender and social background.

On the population level, a considerable increase of the proportion of university graduates in successive birth cohorts can be observed that more than doubled in the second half of the last century. Female enrolment rates, which were only one third of the male rates for the 1930-39 birth cohort have already drawn level with the male rates. Another change over time are the long and increasing study durations until graduation, which, besides the high dropout rates, can be seen as a second typicaland problematic - feature of the Austrian university system ${ }^{3}$. Regarding enrolment duration, some gender differences can be observed: female students study faster-or drop out faster. Accounting for parents' education, the analysis reveals that the strong intergenerational transmission mechanism within families already in place at prior

2 Dropout rates are underreported in the micro-census compared to administrative university enrolment and graduation data. This analysis, based on micro-census data, assumes that unreported university inscriptions have no impact on the other behaviours studied, i. e., they are interpreted as having a negligible effect on other life course careers, e. g., due to shorter durations or low time commitments.

3 This study does not distinguish between university degrees (M.A., Ph.D.). Therefore, a master's degree followed by a doctoral programme is treated as a single educational spell. ${ }^{3}$ 
educational choices is reinforced at the decision about university enrolment and graduation. Put differently, even for people already meeting the admission requirements for university the enrolment and graduation rates vary considerably with respect to their parents' education.

\subsection{Graduation rates}

In the following analysis, the graduation rate is defined as the percentage of students with a Matura diploma who graduate from a university programme. As shown in the table below, the graduation rates are highly dependent on the previous school, municipality type and gender, and follow different patterns over time.

Table 3:

University graduation rates by Matura type, gender and municipality type

\begin{tabular}{|c|c|c|c|c|c|c|c|}
\hline & & & $1940-44$ & $1945-49$ & $1950-54$ & $1955-59$ & $1960-64$ \\
\hline \multirow{4}{*}{ Rural } & \multirow{2}{*}{ Female } & Vocational or Technical Matura & $\begin{array}{l}11.8 \% \\
(\mathrm{n}=17)\end{array}$ & $\begin{array}{c}4.3 \% \\
(\mathrm{n}=23)\end{array}$ & $\begin{array}{l}10.8 \% \\
(\mathrm{n}=37)\end{array}$ & $\begin{array}{c}0.0 \% \\
(\mathrm{n}=66)\end{array}$ & $\begin{array}{c}1.0 \% \\
(\mathrm{n}=98)\end{array}$ \\
\hline & & Academic Matura & $\begin{array}{l}46.2 \% \\
(n=13)\end{array}$ & $\begin{array}{l}22.7 \% \\
(\mathrm{n}=22)\end{array}$ & $\begin{array}{l}15.9 \% \\
(\mathrm{n}=63)\end{array}$ & $\begin{array}{l}18.9 \% \\
(\mathrm{n}=74)\end{array}$ & $\begin{array}{l}20.7 \% \\
(\mathrm{n}=82)\end{array}$ \\
\hline & \multirow{2}{*}{ Male } & Vocational or Technical Matura & $\begin{array}{l}12.1 \% \\
(\mathrm{n}=33)\end{array}$ & $\begin{array}{l}16.7 \% \\
(\mathrm{n}=36)\end{array}$ & $\begin{array}{l}12.5 \% \\
(\mathrm{n}=40)\end{array}$ & $\begin{array}{c}9.3 \% \\
(\mathrm{n}=54)\end{array}$ & $\begin{array}{l}17.3 \% \\
(\mathrm{n}=75)\end{array}$ \\
\hline & & Academic Matura & $\begin{array}{l}72.2 \% \\
(\mathrm{n}=36)\end{array}$ & $\begin{array}{l}60.0 \% \\
(\mathrm{n}=25)\end{array}$ & $\begin{array}{l}45.3 \% \\
(\mathrm{n}=64)\end{array}$ & $\begin{array}{l}40.0 \% \\
(\mathrm{n}=75)\end{array}$ & $\begin{array}{l}40.5 \% \\
(\mathrm{n}=79)\end{array}$ \\
\hline \multirow{4}{*}{ Urban } & \multirow{2}{*}{ Female } & Vocational or Technical Matura & $\begin{array}{c}0.0 \% \\
(\mathrm{n}=35)\end{array}$ & $\begin{array}{c}6.7 \% \\
(\mathrm{n}=45)\end{array}$ & $\begin{array}{l}11.1 \% \\
(\mathrm{n}=27)\end{array}$ & $\begin{array}{c}8.5 \% \\
(\mathrm{n}=47)\end{array}$ & $\begin{array}{c}8.6 \% \\
(\mathrm{n}=58)\end{array}$ \\
\hline & & Academic Matura & $\begin{array}{l}28.6 \% \\
(\mathrm{n}=63)\end{array}$ & $\begin{array}{l}29.0 \% \\
(\mathrm{n}=62)\end{array}$ & $\begin{array}{l}26.2 \% \\
(\mathrm{n}=65)\end{array}$ & $\begin{array}{l}40.4 \% \\
(\mathrm{n}=94)\end{array}$ & $\begin{array}{c}41.3 \% \\
(\mathrm{n}=104)\end{array}$ \\
\hline & \multirow{2}{*}{ Male } & Vocational or Technical Matura & $\begin{array}{l}25.6 \% \\
(\mathrm{n}=43)\end{array}$ & $\begin{array}{c}5.4 \% \\
(\mathrm{n}=37)\end{array}$ & $\begin{array}{l}22.2 \% \\
(\mathrm{n}=45)\end{array}$ & $\begin{array}{l}18.3 \% \\
(\mathrm{n}=60)\end{array}$ & $\begin{array}{l}17.1 \% \\
(\mathrm{n}=70)\end{array}$ \\
\hline & & Academic Matura & $\begin{array}{l}46.8 \% \\
(\mathrm{n}=79)\end{array}$ & $\begin{array}{l}66.2 \% \\
(\mathrm{n}=68)\end{array}$ & $\begin{array}{l}47.9 \% \\
(\mathrm{n}=73)\end{array}$ & $\begin{array}{l}44.2 \% \\
(\mathrm{n}=77)\end{array}$ & $\begin{array}{l}47.7 \% \\
(\mathrm{n}=88)\end{array}$ \\
\hline
\end{tabular}

Source: Micro-Census June 1996, special programme on education

Due to the small sample size which does not permit a meaningful further disaggregation of data, a logistic regression model was calculated in order to study the influence of parents' educational attainment and the general time trend on the graduation rates of eight groups built by gender, municipality type and previous schooling. 
Table 4:

Logistic regression for staying with Matura as highest educational attainment

\begin{tabular}{|c|c|c|c|c|c|c|c|c|c|}
\hline & & $\begin{array}{l}\text { Urban Male } \\
\text { "Academic } \\
\text { Matura" }\end{array}$ & $\begin{array}{l}\text { Urban Male } \\
\text { "Vocational } \\
\text { Matura" }\end{array}$ & $\begin{array}{l}\text { Urban } \\
\text { Female } \\
\text { "Academic } \\
\text { Matura" }\end{array}$ & $\begin{array}{l}\text { Urban } \\
\text { Female } \\
\text { "Vocational } \\
\text { Matura" }\end{array}$ & $\begin{array}{l}\text { Rural Male } \\
\text { "Academic } \\
\text { Matura" }\end{array}$ & $\begin{array}{l}\text { Rural Male } \\
\text { "Vocational } \\
\text { Matura" }\end{array}$ & $\begin{array}{l}\text { Rural } \\
\text { Female } \\
\text { "Academic } \\
\text { Matura" }\end{array}$ & $\begin{array}{l}\text { Rural } \\
\text { Female } \\
\text { "Vocational } \\
\text { Matura" }\end{array}$ \\
\hline & Intercept & $\begin{array}{c}0.125 \\
(0.582)\end{array}$ & $\begin{array}{c}2.895^{* *} \\
(1.141)\end{array}$ & $\begin{array}{c}3.848 * * * \\
(0.793)\end{array}$ & $\begin{array}{c}5.475^{* * * *} \\
(1.913)\end{array}$ & $\begin{array}{c}-2.058 * * * \\
(0.791)\end{array}$ & $\begin{array}{l}1.819^{*} \\
(1.063)\end{array}$ & $\begin{array}{c}1.546 \\
(1.154)\end{array}$ & $\begin{array}{l}-0.758 \\
(2.156)\end{array}$ \\
\hline & Cohort & $\begin{array}{c}0.027 \\
(0.076)\end{array}$ & $\begin{array}{c}0.007 \\
(0.126)\end{array}$ & $\begin{array}{c}-0.308 * * * \\
(0.090)\end{array}$ & $\begin{array}{l}-0.228 \\
(0.218)\end{array}$ & $\begin{array}{c}0.348^{* * * *} \\
(0.105)\end{array}$ & $\begin{array}{l}-0.023 \\
(0.139)\end{array}$ & $\begin{array}{c}0.112 \\
(0.142)\end{array}$ & $\begin{array}{c}0.625^{* *} \\
(0.285)\end{array}$ \\
\hline 룽 & University & $\begin{array}{c}-0.859 * * \\
(0.335)\end{array}$ & $\begin{array}{c}-2.460 * * * \\
(0.854)\end{array}$ & $\begin{array}{c}-1.937 \text { *** } \\
(0.447)\end{array}$ & $\begin{array}{c}-2.389 * * \\
(1.211)\end{array}$ & $\begin{array}{c}-1.026 * * \\
(0.411)\end{array}$ & $\begin{array}{l}-0.058 \\
(0.832)\end{array}$ & $\begin{array}{c}-2.345^{* * *} \\
(0.527)\end{array}$ & $\begin{array}{l}-1.298 \\
(1.305)\end{array}$ \\
\hline 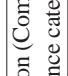 & Matura & $\begin{array}{l}-0.276 \\
(0.335)\end{array}$ & $\begin{array}{c}-1.487 * \\
(0.806)\end{array}$ & $\begin{array}{l}-0.699 \\
(0.456)\end{array}$ & $\begin{array}{l}-0.628 \\
(1.244)\end{array}$ & $\begin{array}{l}-0.630 \\
(0.389)\end{array}$ & $\begin{array}{c}1.343 \\
(1.063)\end{array}$ & $\begin{array}{c}-2.145 * * * \\
(0.533)\end{array}$ & $\begin{array}{l}-1.598 \\
(1.008)\end{array}$ \\
\hline 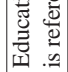 & Vocational & $\begin{array}{c}0.170 \\
(0.467)\end{array}$ & $\begin{array}{c}-1.850 * * \\
(0.815)\end{array}$ & $\begin{array}{l}-0.771 \\
(0.533)\end{array}$ & $\begin{array}{c}-2.599 * * \\
(1.116)\end{array}$ & $\begin{array}{c}-1.696^{* * * *} \\
(0.535)\end{array}$ & $\begin{array}{c}0.477 \\
(0.674)\end{array}$ & $\begin{array}{l}-0.936 \\
(0.601)\end{array}$ & $\begin{array}{l}17.894 \\
(0.000)\end{array}$ \\
\hline 竭 & $\begin{array}{l}\text { Appren- } \\
\text { ticeship }\end{array}$ & $\begin{array}{l}-0.016 \\
(0.365)\end{array}$ & $\begin{array}{l}-1.308^{*} \\
(0.788)\end{array}$ & $\begin{array}{l}-0.511 \\
(0.480)\end{array}$ & $\begin{array}{c}0.154 \\
(1.436)\end{array}$ & $\begin{array}{l}-0.212 \\
(0.360)\end{array}$ & $\begin{array}{c}0.103 \\
(0.449)\end{array}$ & $\begin{array}{l}-0.712 \\
(0.536)\end{array}$ & $\begin{array}{l}-0.674 \\
(1.026)\end{array}$ \\
\hline
\end{tabular}

Models estimated from the June 1996 Micro-Census data; significance levels are indicated by *** over $99 \%$, ** over $95 \%$ and $*$ over $90 \%$

The regression results indicate a clear ranking of probabilities by parents' education. Especially the influence of parents with an academic education is highly significant in most groups. Looking at the time trends in different groups, an interesting pattern arises.

No cohort effect can be found for urban male students. This means that the rising number of students obtaining a Matura diploma can be directly translated into higher numbers of university graduates, as graduation rates remained unchanged over time. Graduation rates are highest for students with parents who graduated from university and vary from $40 \%$ to $65 \%$ (academic Matura) or 5\% to $40 \%$ (vocational and technical Matura) respectively. 
Figure 9:

Observed and estimated graduation rates for urban males coming from (1) a secondary academic school and (2) vocational or technical colleges. Source: Logistic regression models estimated from the June 1996 Micro-Census data
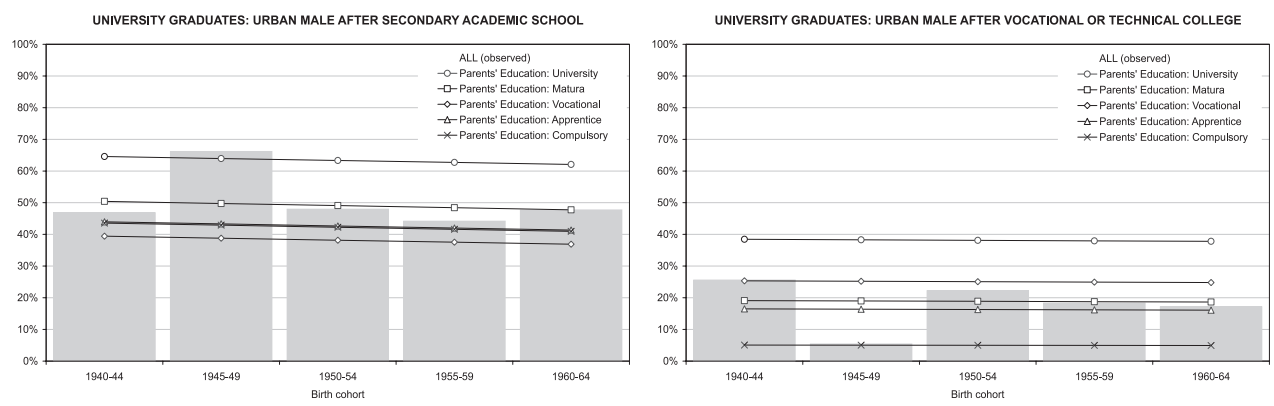

A very different picture emerges for urban females. In this group, graduation rates increased considerably over the last decades and the influence of parents' education is even more pronounced, with university graduation rates ranging from $25 \%$ to $70 \%$ for students with an academic Matura.

\section{Figure 10:}

Observed and estimated graduation rates for urban females coming from (1) a secondary academic school and (2) vocational or technical colleges. Source: Logistic regression models estimated from the June 1996 Micro-Census data
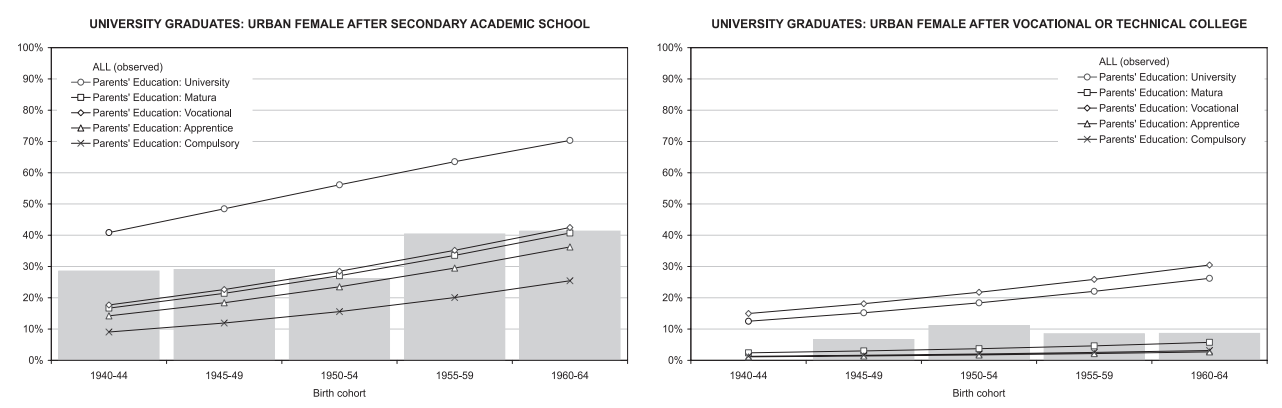

For rural males with an academic Matura, graduation rates decreased considerably over time. While attending secondary academic school was highly selective for rural males in the past and most (70\%) of the few who reached Matura level graduated from university afterwards, graduation rates dropped and stabilised at "urban levels". No such change is observed for students from vocational and technical colleges, for whom graduation rates remained stable at the level of urban areas. 
Figure 11:

Observed and estimated graduation rates for rural males coming from a (1) secondary academic school and (2) vocational or technical colleges. Source: Logistic regression models estimated from the June 1996 Micro-Census data
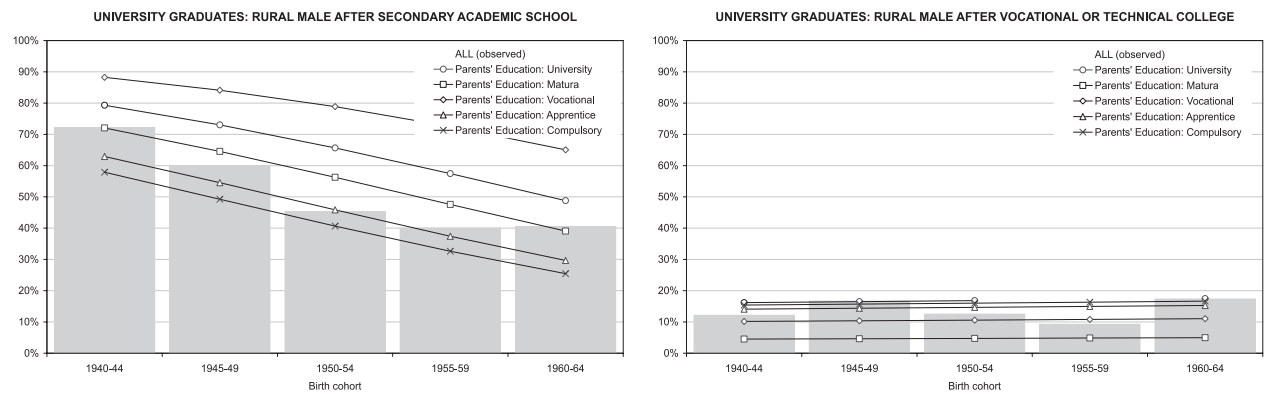

For students with an academic Matura diploma, graduation rates are lowest for rural females that reach only half the level of all other groups whose rates converged over time at around $40 \%$. While there are no significant cohort effects in this group, parents' education has a highly significant and very pronounced impact on graduation rates that range from $8 \%$ to $45 \%$, with a clear ranking by parents' educational level. Graduation rates are lowest for rural females who completed vocational and technical colleges.

Figure 12:

Observed and estimated graduation rates for rural females from (1) a secondary academic school and (2) vocational or technical colleges. Source: Logistic regression models estimated from the June 1996 Micro-Census data
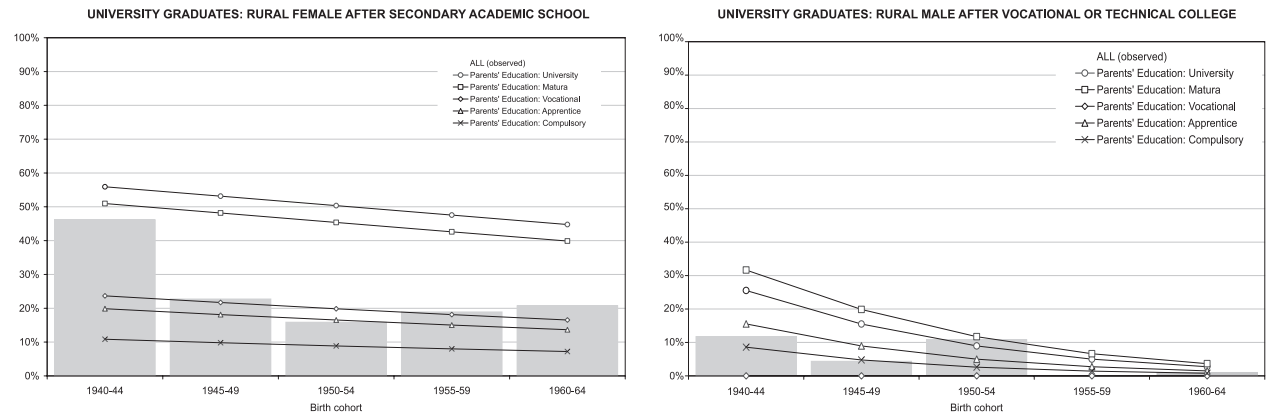

The following figure summarises the (estimated) graduation rates for all groups considered. 
Figure 13:

Estimated graduation rates after (1) a secondary academic school and (2) vocational or technical colleges. Source: Logistic regression models estimated from the June 1996 Micro-Census data


\subsection{University dropouts and study durations}

Although university dropouts do not reach an additional educational level beyond the Matura diploma, their explicit consideration in the microsimulation model developed below is necessary in order to avoid distortions in the school leaving age which has a key impact on the timing of births. Regarding dropout rates measured as percentage of students enrolled at university without graduation, no significant time trend could be observed in the micro-census data. Dropout rates are lower for students having a vocational or technical Matura diploma, which can be explained by higher selectivity, as considerably fewer students of this group enter university. Dropout rates vary considerable with parents' education and gender, being highest for female students with parents of the lower educational strata.

With a mean value of 7.3 years for the graduation cohorts 1990-96, study durations in Austria far exceed the durations set out in the curricula for most fields of studies. Our analysis of study durations does not distinguish between university degrees (M.A., Ph.D.) and therefore treats master's programmes followed by a doctoral study as one educational spell. Study durations reported in the micro-census nevertheless closely correspond to those based on administrative data. Landler (2000) calculated median study durations of 7.5 and 10 years, respectively, until obtaining a master's or doctoral degree respectively.

Durations are longer for male students, for students with an academic Matura and for students coming from urban areas. Gender differentials are not only found in the mean study duration but also in the shape of the duration distribution. While considerably more female students finish within the regular time, $40 \%$ of both male and female students complete their studies within a maximum of six years. Of the $60 \%$ of students studying more than six years, male students stay considerably longer at university. 
Figure 14:

Distribution of study durations by gender, graduation cohort 1990-96.

Source: Micro-Census June 1996

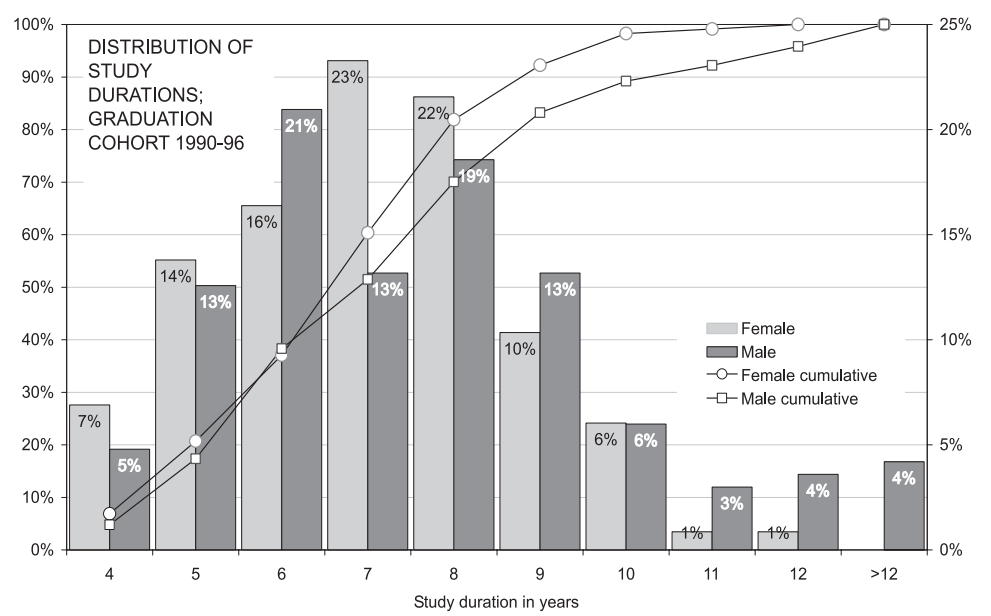

Enrolment durations of university dropouts decreased over time, with $50 \%$ of the students leaving university in 1990-96 in the first year. Female students drop out faster, with $75 \%$ (versus $56 \%$ ) in the first two years.

The results of our analysis support the findings of other studies. Wroblewski and Unger (2003) made a comprehensive analysis of the social background of first-year students. While 45\% (1990: 44\%) of those enrolled in 2001 had a father with higher education, this group comprised only $22 \%$ (1991: 14.8\%) of the resident population. Regarding the parents' education and profession, Dell'mour and Landler (2002) calculate success rates for different cohorts and find them, at 58\%, to be highest for those students whose fathers have an academic degree. The second-best prospect to graduate successfully from university have students whose fathers have a Matura degree (49\%), followed by those with compulsory education as the highest educational attainment. According to the authors, students having a father who graduated from university or who holds a Matura degree display above-average success rates for the cohorts considered (1980-85). Our data confirm these findings. However, since in our analysis we do not only take into account the educational attainment of parents but additionally disaggregate by gender and municipality type, we are able to make more precise statements. When considering graduates of secondary academic schools who grew up in rural areas and whose parents have a vocational education, we find males having very good prospects of graduating (65\%), while not even one fifth of the females with the same characteristics obtain a university degree.

Concerning the gender ratio of graduates, Landler (1997) finds that $40 \%$ of the graduates are females. This proportion was constant between 1989 and 1993 and has increased only slightly in the years prior to 1989 . While our calculations are consistent with the findings of Landler for the former period, females will soon catch up with males according to our projections. 
Our analyses do not include Fachhochschulen, since they were introduced in 1994/95 and therefore not covered in the micro-census data. According to Wroblewski and Unger (2003), Fachhochschulen differ considerably from universities with regard to the social structure and regional provenance of their students.

\section{Final educational attainment and intergenerational mobility}

The following figure gives a graphical representation of the final educational attainment by gender, municipality type and parents' education. In this graph we additionally group the final educational attainments by those with and without a Matura diploma (right and left side bars respectively). The probabilities of obtaining a Matura degree or graduating from university are almost ranked by parent's education. However, within each level of parental education, considerable variation remains, caused by municipality type and gender.

\section{Figure 15:}

Final educational attainment by gender, municipality type and parents' education.

Source: Micro-Census June 1996



An alternative way of looking at the data is by asking how many children obtain a higher, equal or lower education than their parents. In contrast to the comparison between the rates for different educational attainment which indicate considerable socio-economic differentials and therefore a strong intergenerational persistence of educational attainments within families, the representation of these data rather highlights existing social dynamics. 
Figure 16:

Intergenerational educational change. Source: Micro-Census June 1996

INTERGENERATIONAL EDUCATIONAL CHANGE BY SEX, REGION AND PARENTS' EDUCATION

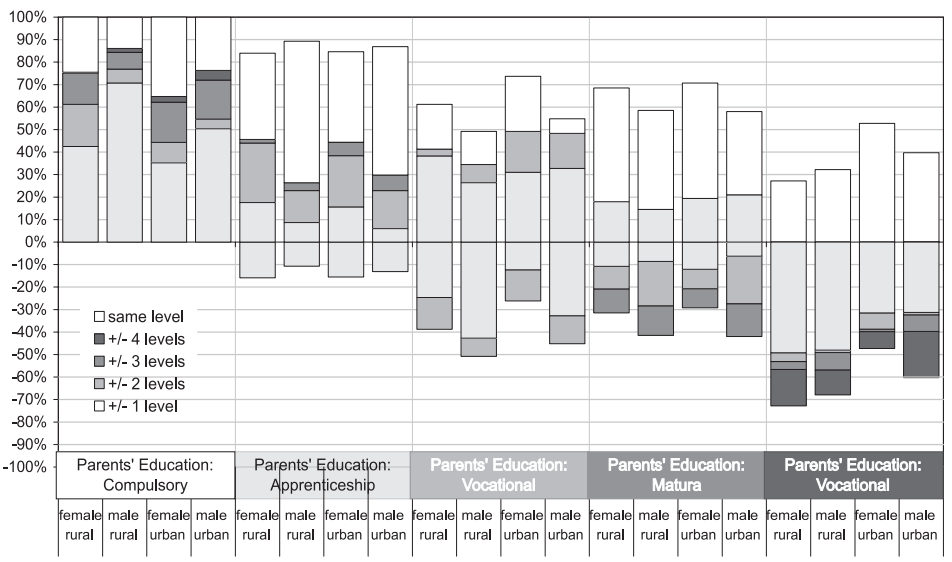

In the group of students with parents who have only compulsory education, about three-quarters obtain a higher education. There are considerable gender differentials with females, who are more likely to attain compulsory education only. The highest intergenerational persistence of educational attainments is found in the apprenticeship group: almost two-thirds of the rural males of this group follow the same educational track. On the other side of the educational spectrum we find the offspring of university graduates who can only reach, or fall below, their parents' educational level. Urban females are most likely to graduate from university (53\%), but on average around $60 \%$ do not reach the same educational level.

A second observation regards the degree of the intergenerational differences in educational attainment. Most changes are one-level changes, e. g., if parents have compulsory education, most of the offspring who attain a higher educational level move into the apprenticeship group (83\% of rural males). On the other side, more than $70 \%$ of the offspring of university graduates who do not graduate from university obtain a Matura diploma.

As pointed out above, the individual graduation rates have stayed almost unchanged for the past two decades regarding secondary education, and they converged to the same rates regarding university graduation for most groups, however with persistent differentials by parents' education. Thus, the assumption of time-invariant behaviours for the future based on most recent graduation rates can be regarded as a reasonable baseline scenario for educational projections. What does this mean for the future? Assuming unchanged behavioural relations on the micro level also for the future, the population will reach a stable equilibrium in its educational composition. This long-term equilibrium - and the speed at which it is reached—is determined by the social dynamics. What will the resulting educational composition of the population look like? This question will be discussed next, when we project the transition path under this status quo assumption. 


\section{The family and education microsimulation model ${ }^{4}$}

In order to make projections of the future educational composition of the Austrian population, we use the FAMSIM+ microsimulation model. FAMSIM+ is a general, dynamic, data based, closed population microsimulation projection model. The starting population was generated from the second wave of the 1996 Austrian micro-census (Schwarz and Spielauer 2003). The model consists of four behavioural modules on mortality, education, partner matching and fertility. Transition rates and duration distributions are assumed to be time-invariant, i. e., the model is parameterised by time-invariant transition rates and duration distributions. The following section gives an overview of the parameterisation of the model.

\subsection{Education}

All individuals enter primary school in September following their $6^{\text {th }}$ birthday. Regarding all school transitions and education durations, we distinguish between 20 "student types" according to parents' education, sex and municipality type. Each school is parameterised by the duration distribution (in years) and transition rates into all possible subsequent school types. The parameterisation follows the analysis above. Additionally, duration distributions are calculated and modelled for upper secondary and university education. University dropouts are modelled separately, based on estimated dropout rates and using a logistic regression model. Again, the gender-specific distribution of the study duration observed is used for the parameterisation of the baseline model. In addition to the school types discussed above, an additional school type, "Short Colleges", was modelled in order to account for all additional finished or unfinished secondary or tertiary education spells which (in our model) do not lead to a higher educational level but influence the school leaving age.

\subsection{Partnerships}

A change in the educational composition of the population implies changes of the matching patterns of couples over time. For Austria, this change can be described as a move from an asymmetric educational composition of couples (with many women having a partner with a higher education and only few women whose partner has a lower education) to a symmetric situation, in which both groups are of the same size. For married couples, the percentage of women having partners with a higher education decreased from initially $40 \%$ to $30 \%$ over the last five decades, while the percentage of women having partners with a lower education increased from below $10 \%$

4 A full description of the model including its parameterisation can be found in Spielauer et. al. (2003) and Spielauer (2003). For a description of the FAMSIM+ microsimulation platform see also Spielauer (2002) 
to $30 \%$, resulting in a symmetric pattern. Partnerships are highly homogamous, with around $90 \%$ of partners coming from the same or an adjacent educational group. We assume that the matching pattern by education as observed today will remain stable. Being a closed microsimulation model, consistency is enforced as couples are linked in the simulation. Therefore, microsimulation can be used to see if current behaviours can be maintained in the future, which is true in our case ${ }^{5}$. For a detailed analysis of matching pattern by education, see Schwarz and Spielauer (2002).

In the simulation, a partner is matched to a woman when giving first birth. This means that fertility is modelled independently of partnership status. Partners are matched using observed educational and age patterns. As only the educational attainment of the male partner is used in the simulation, age differences are included in the model merely in order to enforce more consistency. Rather than modelling partnership careers from formation to end by divorce, separation or a partner's death, only death is considered in this model: the death of a partner terminates the partnership career and in the case of giving birth, a new male partner is matched. We assume that this simple model is sufficient for educational projections, as only the educational level of the father is used in the projection model.

\subsection{Fertility}

Being interested in the intergenerational education transmission processes within families and the resulting future educational composition of the population, we need to account for fertility differentials between these educational groups. Behavioural differences regarding the quantum and timing of birth by educational group are considerable in Austria. Changes over time follow patterns summarised under the terms of the first and second demographic transition (Lesthaeghe and van der Kaa, 1986). Regarding the number of births, the first transition is linked to the emergence of the "two-child norm", with fewer women staying childless and a sharp decrease of higher order parity progression rates. As discussed in Spielauer et al. (2004) this pattern can easily be identified for Austria. From the 1945 birth cohorts onwards, a movement back to less uniform fertility behaviours, e. g., higher rates of childlessness of higher educated women, can be observed, with parity progression rates decreasing for all birth orders. A comparison of cohort fertility rates by education for

5 The simulation is based on the following algorithm: at any birth event, it is determined if a partner has to be matched. If so, the partner's educational attainment and age (in years) is determined by Monte-Carlo simulation. In the next step, a partner with these characteristics is searched in the population database and matched if found. If no partner can be found, another random draw of the partners' age is made until a partner with the educational characteristics can be found or a maximum number of iterations is reached. In the latter case, no partner is matched explicitly. The number of repetitions is stored for further analysis. In the simulation runs based on this model, in around $94 \%$ of the cases no repetition is needed and in $99.6 \%$ less than three repetitions are needed indicating that the future "spouse market" allows for unchanged matching patterns. 
the birth cohorts 1935-1954 reveals very different levels of fertility as well as different patterns of change over time.

The fertility module implemented in the microsimulation model follows a simple scenario-based approach. The timing of birth is modelled in dependence on the school leaving age, assuming time-invariant distributions of the duration from leaving school to the first birth for different educational groups and also taking into account rural-urban differentials. Regarding the timing and spacing of birth, we use period data derived from micro-census data for the first birth and census data for the spacing of birth.

The quantum of birth is parameterised by time-invariant parity distributions, i. e., for every distinguished group of women it is specified how many of them remain childless, have one child, two children etc. over their life courses. In the simulation, we first determine for each woman if she will give birth (again) or not, using Monte Carlo simulation based on the individual parity progression rate calculated from the model parameters. If so, the duration from the reference event (school leaving for first birth or last birth respectively) is determined by Monte Carlo simulation.

In order to parameterise the model, parity distributions have to be set for all educational and rural-urban groups distinguished. As those measures are not observable for the present, a scenario was developed that produces simulated births consistent with observed births by educational group since 1996 in a retrospective projection. We use a base scenario which assumes a convergence of fertility rates into two regimes: the cohort fertility rates of women without a Matura diploma are assumed to be close to replacement at 2.0 in rural and 1.9 in urban areas, while being at 1.35 for women with Matura. The fertility differential between the two main groups (with/without Matura) is kept rather moderate to stay "on the safe side" when analysing the influence of the fertility differentials on the future educational composition of the population. As the model currently does not consider rural-urban migration, which might lead to distortions especially regarding higher educated groups, a unique fertility level is assumed for rural and urban women with a Matura diploma. On the population level, this parameterisation results in a cohort fertility rate of 1,623 , when a stable equilibrium in the educational composition of the population is reached. This cohort fertility rate is considerably higher than the currently observed periodic total fertility rate, which does not account for the changes in the timing of birth. It is comparable with the central scenario of the UN population projection for Austria which assumes that the total fertility rate will increase to 1.65 until 2050. The number of births projected in the base scenario will stay close to the central scenario made by Statistics Austria for the next two decades and then fall considerably below it. This difference can mainly be explained by the non-consideration of immigration in our model. Beside the base scenario, an alternative scenario is created in order to investigate the effect of fertility differentials by education on the educational composition of the population. In the alternative scenario all women are assumed to have the same parity distribution and, therefore, the same cohort fertility. 


\subsection{Mortality}

The month of death is determined at birth or, respectively, in the starting period (June 1996) of the simulation for persons of the starting population. We use the 1991 mortality tables for males and females.

\section{The future educational composition of the Austrian population: projection results}

The micro-projection of the future educational composition of the population by birth cohort indicates a continuing educational expansion on the population level. As the microsimulation model assumes unchanged behaviours on the micro level expressed in fixed (time-invariant) transition rates and duration distributions, the population converges towards a stable equilibrium with a stable educational composition.

In urban areas, almost a quarter of the population will have an academic degree and around one third will have a Matura diploma as the highest educational attainment. In rural areas, university graduates will account only for one ninth of the population.

Figure 17:

Educational composition of the population by birth cohort and in the equilibrium state SIMULATION: EDUCATIONAL COMPOSITION OF THE POPULATION BY BIRTH COHORT

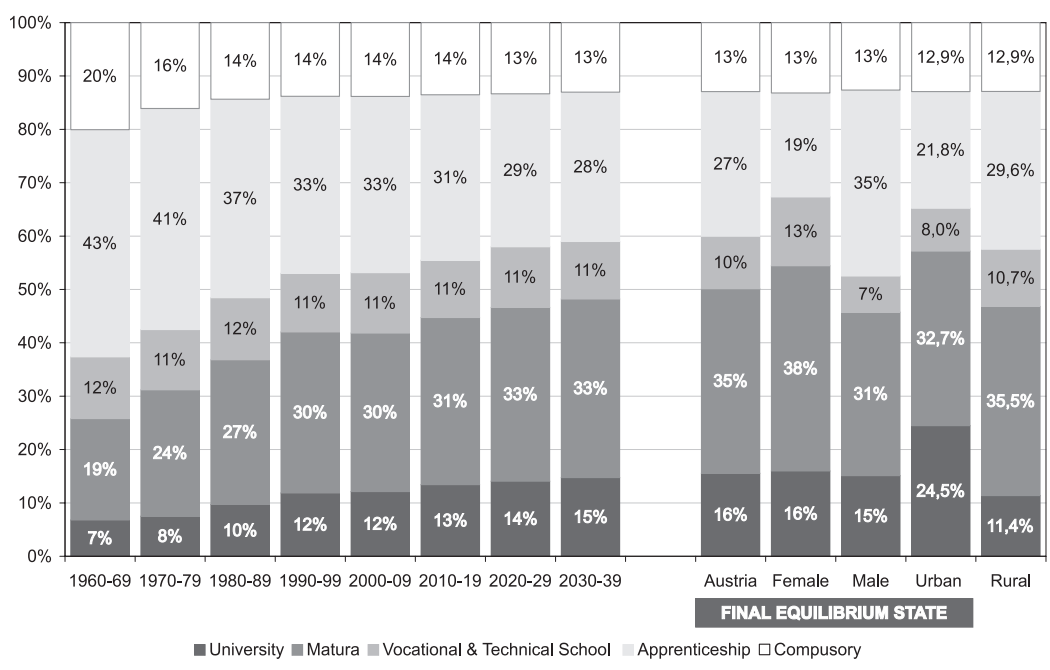

The decomposition of this aggregated simulation projection result by municipality type reveals that most changes regarding birth cohorts from 1990 onwards occur in rural areas. While the percentage of university graduates is three times higher in urban areas for the 1990-99 birth cohorts, the rural university graduation rate is expected to reach half the level of the urban rate for the 2030-39 birth cohort. 
Figure 18:

Educational composition of the population by birth cohort and municipality type

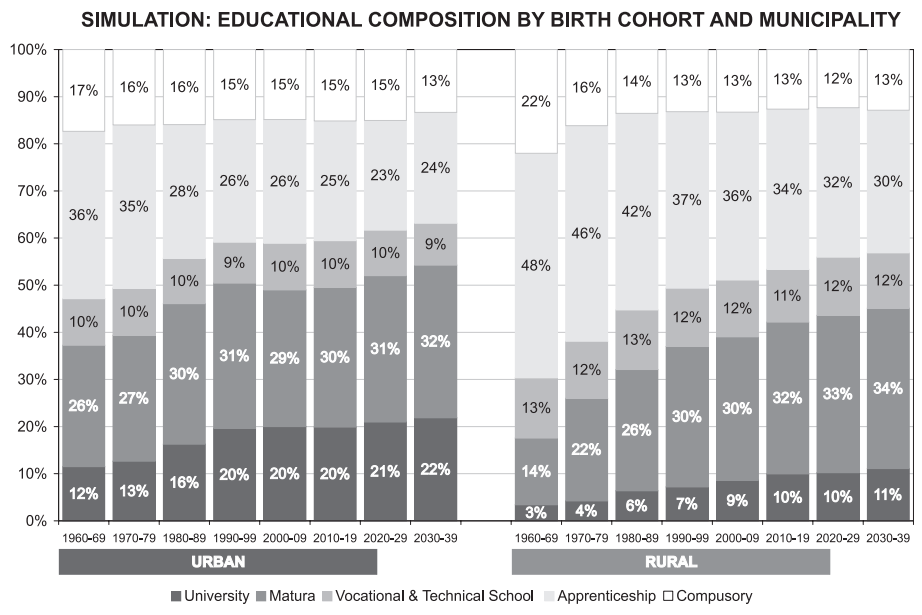

Fertility differentials between the educational groups result in lower rates of university graduates and people with a Matura diploma when compared to a scenario of uniform fertility among educational groups. Without fertility differentials, the rate of university graduates would be $15 \%$ higher, while the percentage of the apprenticeship group would be $14 \%$ lower.

\section{Figure 19:}

Relative change of the size of educational groups in a uniform fertility scenario compared to the base scenario

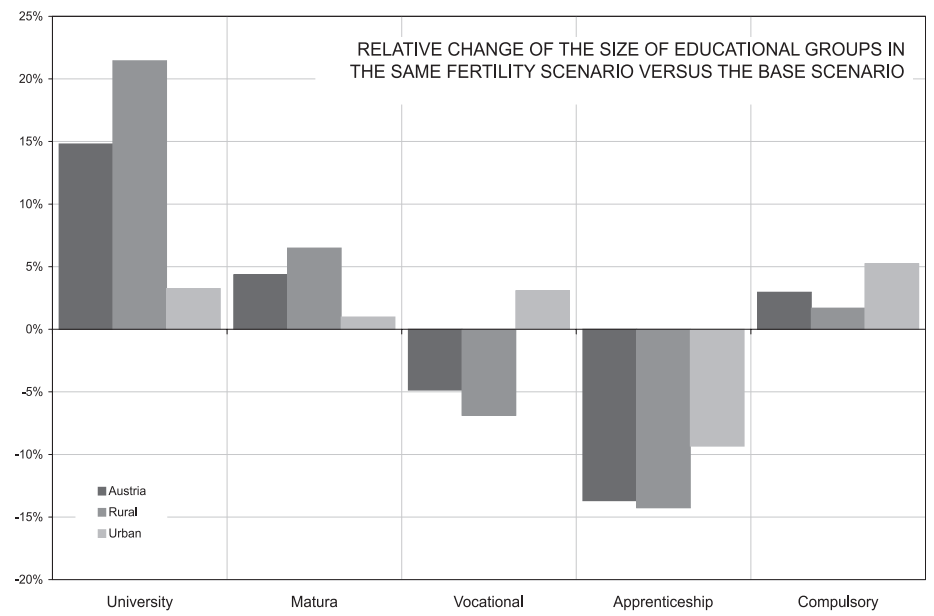

While fertility differentials by education considerably impact on the future educational composition of the population, even with uniform fertility the percentage of university graduates would stay at rather moderate levels in an international compar- 
ison. In other words, we believe that only an improved access of the lower social strata to higher education could trigger a continuing educational expansion beyond the rather moderate expansion that can be expected for the future under our model assumptions. In this respect, the introduction of Fachhochschulen (universities of applied sciences) in 1994/95 and their considerable success in the last years might point into the right direction.

\section{Summary}

In the last decades we observed a considerable educational expansion in Austria: with each age cohort; an increasing number of people reached higher levels of education. In contrast to this trend at the population level, very stable behavioural relationships are found on the micro level when accounting for parental educational attainment, rural-urban differentials and gender. The education of parents was identified as the key determinant of individual school careers, being reinforced at every transition point. Regarding the first educational choice between the lower secondary and the lower secondary academic school, we find probabilities to opt for the latter, ranging from $7 \%$ for rural boys with parents that have only compulsory education to $86 \%$ for urban girls with at least one parent with a university diploma. For the first group, the probability to obtain a Matura diploma is $9.4 \%$, compared to $84.3 \%$ of the latter. With respect to university education, the range between these two groups is from $1.8 \%$ to $52.8 \%$, or in other words, daughters of university graduates in cities have a thirty times higher probability to obtain a university diploma than sons of parents with compulsory education living in rural areas.

Assuming unchanged behavioural relations on the micro level, the educational composition of the population converges towards a stable equilibrium. In order to study the transition path as well as the resulting equilibrium, we considered additional processes that influence the future educational composition of the Austrian population: partnership formation and fertility. We applied the FAMSIM+ microsimulation model to project the future educational composition of the population. In order to determine the effect of fertility differentials on this equilibrium, we also ran a second scenario of uniform fertility behaviours and used the resulting equilibriums for comparative analysis. While fertility differentials slow down educational expansion and lead to a considerably lower equilibrium state of the future educational composition of the population, the main obstacle for a greater dynamic lies in the unequal access of the lower social strata to higher education.

Under our assumptions, the educational expansion we experienced in the last decades will continue at a very moderate speed in the next decades until the equilibrium is reached. In the future equilibrium, half of the population will obtain a Matura diploma of which $30 \%$ will also graduate from university. Regarding higher education, the introduction of Fachhochschulen (universities of applied sciences) in 1994/95 might trigger an educational expansion beyond our rather pessimistic scenario. But 
without changes in the very early and strong social selection processes, the prospects of a more substantial expansion are limited.

\section{Acknowledgements}

This paper is heavily based on parts of my doctoral thesis (Spielauer 2003) in which I developed the underlying technical microsimulation framework, including its computer implementation. I am thankful to Wolfgang Lutz for the supervision of my thesis, support and scientific advice. This article also draws on a series of working papers (Schwarz and Spielauer 2002, Schwarz and Spielauer 2003, Spielauer 2002) and a report produced by the author together with Franz Schwarz, Karin Städtner and Kurt Schmid at the Austrian Institute for Family Studies (Spielauer et al., 2004).

I am also thankful to Susann Backer from the Max Planck Institute for Demographic Research for the careful language editing of this contribution.

Martin Spielauer currently works as a research scientist at the Max Planck Institute for Demographic Research in Rostock, Germany. Most of the research presented in this paper was conducted during his previous positions as leader of the socioeconomic research department of the Austrian Institute for Family Studies and as Research Scholar at the International Institute for Applied Systems Analysis.

\section{References}

Bacher J. 2003. Soziale Ungleichheit und Bildungspartizipation im weiterführenden Schulsystem Österreichs. Österreichische Zeitschrift für Soziologie, 3/2003.

Bauer, A. 1996. Volkszählung 1991: Ausbildung und sozioökonomische Zugehörigkeit der Eltern. Statistische Nachrichten 5/1996. Vienna: ÖSTAT

Biffl, G. 2002. Der Bildungswandel in Österreich in den Neunziger Jahren. WIFO-Monatsberichte 6/2002. 377-384. Vienna.

Blossfeld, H.-P. 1988. Bildungsverläufe im historischen Wandel - Eine Längsschnittanalyse über die Veränderung der Bildungsbeteiligung im Lebenslauf dreier Geburtskohorten. In: H.-J. Bodenhöfer (ed.) Bildung, Beruf, Arbeitsmarkt. Schriftenreihe des Vereins für Sozialpolitik, Bd. 174. p. 259-302. Duncker \& Humblot,. Berlin.

Blossfeld, H.-P. 1988. Sensible Phasen im Bildungsverlauf - Eine Längsschnittanalyse über die Prägung von Bildungskarrieren durch den gesellschaftlichen Wandel. Zeitschrift für Pädagogik, 34, 45-63.

Bm:bwk. 2001. Kenndaten des österreichischen Schulwesens 2001. Vienna: Bundesministerium für Bildung, Wissenschaft und Kultur,.

Bm:bwk. 2004. Bildungswesen in Österreich. Das heutige Schulsystem. Vienna: Bundesministerium für Bildung, Wissenschaft und Kultur, 
Dell'mour, R., F. Landler. 2000. Quantitative Entwicklungstendenzen der österreichischen Hochschulen 1973-2020. Vienna: Institut für Demographie.

Dell'mour, R., F. Landler. 2002. Akademische Grade zwischen Traum und Wirklichkeit - Einflussfaktoren auf den Studienerfolg. Vienna: Institut für Demographie

Galler, H. P. 1997. Discrete-Time and Continuous-Time Approaches to Dynamic Microsimulation Reconsidered. Technical Paper 13. Canberra: National Centre for Social and Economic Modeling. University of Canberra.

Henz, U. 1997. Die Messung der intergenerationalen Vererbung von Bildungsungleichheit am Beispiel von Schulformwechseln und nachgeholten Bildungsabschlüssen. In: Becker, Rolf (edt.) Generationen und sozialer Wandel. Leske + Budrich, Opladen.

Hoem, J., A. Prskawetz and G. Neyer. 2001. Autonomy or conservative adjustment? The effect of public policies and educational attainment on third births in Austria. MPIDR Working Paper WP 2001-016.Rostock: Max Planck Institute for Demographic Research.

Klemm, K. 2000. Bildung. In: Allmendinger, J. and Ludwig-Mayerhofer (Eds.): Soziologie des Sozialstaates. Weinheim 2000, S.145-165.

Klevmarken, N. A. 1997. Behavioural Modeling in Micro Simulation Models. A Survey. Working Paper 1997:31, Department of Economics. Uppsala: Uppsala University.

Landler, F. 1997. Das österreichische Bildungswesen in Zahlen-Analyse und Computersimulation des Schulsystems und der Qualifikationsstruktur der Bevölkerung Vienna: WUV-Universitätsverlag.

Lassnigg, L., A. Paseka (Hrsg.). 1997. Schule weiblich - Schule männlich: Zum Geschlechterverhältnis im Bildungswesen. Innsbruck: Studienverlag.

Lassnigg, L. 2000. Zehn Thesen zur Entwicklung von Bildung-Erziehung in Österreich. Thesenpapier zum Jubiläumskongress der Österreichischen Gesellschaft für Soziologie.Vienna

Lechner, F., W. Reiter. 1998. Die Sozialstruktur der Studierenden-Entwicklung und Stand seit der „Öffnung der Hochschulen“. Vienna: Wissenschaftsverlag.

Lesthaeghe, R. D. van de Kaa. 1986. Twee demografische transities?. In: Lesthaeghe and van de Kaa (eds): Bevolking: groei en krimp, Mens en Maatschappij, book supplement, Van Loghum Slaterus, Deventer: 9-24.

Lutz, W., J. W. Vaupel and D. A. Ahlburg (Eds.). 1999. Frontiers of Population Forecasting. Population and Development Review, 24 (Supplement) New York: Population Council.

O'Donoghue, C. 2001. Redistribution in the Irish Tax-Benefit System. PhD thesis at the London School of Economics. LSE. London.

Orcutt, G. 1957. A New Type of Socio-economic System. Review of Economics and Statistics, 58:773-797.

Prenner, P. 2000. Qualifikation und Erwerbsarbeit von Frauen von 1970-2000 in Österreich. Vienna: AK. 
Schmid, K. 2003. Regional flows of education in Austria; Institut für Bildung der Wirtschaft, ibw research brief No. 3. Vienna

Schwarz, F., M. Spielauer. 2002. The Composition of Couples According to Education and Age. An Analysis in the Context of the FAMSIM+ Family Microsimulation Model for Austria, ÖIF Working Paper Nr. 26, Vienna: Austrian Institute of Family Studies

Schwarz, F., M. Spielauer. 2003. FAMSIM+ Population Database: General Framework and the Starting Population for Educational Projections. ÖIF Technical Paper 1, Vienna: Austrian Institute of Family Studies.

Shavit, Y., H.-P. Blossfeld. 1993. Persistent Inequality: Changing Educational attainment in Thirteen Countries. Boulder CO. Westview Press.

Spielauer, M., C. Vencatasawmy 2003. FAMSIM: Dynamic Microsimulation of Life Course Interactions between Education, Work, Partnership Formation and Birth in Austria, Belgium, Italy, Spain and Sweden-Vienna Yearbook of Population Research 2003-A Scientific Yearbook. Vienna.

Spielauer, M. 2001. Microsimulation Modeling of Population, Economic Growth, and Social Security Systems. IIASA Interim Report IR-01-026. Laxenburg: International Institute for Applied Systems Analysis.

Spielauer, M. 2002. The Potential of Dynamic Microsimulation in Family Studies: A Review and some Lessons for FAMSIM+. ÖIF Working Paper 18-2002. Vienna: Austrian Institute for Family Studies.

Spielauer, M. 2003. A Dynamic Socio-Demographic Microsimulation Model for Austria: General Framework and an Application for Educational Projections; Doctoral Thesis at the University of Vienna

Spielauer, M., F. Schwarz, K. Städtner and K. Schmid. 2004. Family and Education. Intergenerational educational transmission within families and the influence of education on partner choice and fertility. Analysis and microsimulation projection for Austria. ÖIF Schriftenreihe (forthcoming) Vienna: Austrian Institute for Family Studies

Vencatasawmy, C. 2002. Modeling Fertility in a Life Course Context: Some Issues. ÖIF Working Paper 17-2002. Vienna: Austrian Institute for Family Studies.

Wroblewski, A. M. Unger. 2003. Studierenden Sozialerhebung 2002. Bericht zur Sozialen Lage der Studierenden. IHS. Vienna: Institut für Höhere Studien. 